\title{
PENGARUH MENTAL DAN MODAL BERWIRAUSAHA TERHADAP MINAT BERWIRAUSAHA DENGAN MOTIVASI SEBAGAI VARIABEL INTERVENING PADA MAHASISWA PENDIDIKAN EKONOMI UNIVERSITAS NEGERI MEDAN
}

\author{
Putri Kemala Dewi Lubis ${ }^{1{ }^{*}}$, Juli Maharajni Maha ${ }^{1)}$ \\ ${ }^{1)}$ Fakultas Ekonomi, Universitas Negeri Medan \\ *Penulis Korespondensi: putrikemala@unimed.ac.id \\ 2)julimahaa@gmail.com
}

\begin{abstract}
Permasalahan dalam penelitian ini adalah mental berwirausaha dan modal berwirausaha yang minim mengakibatkan minat berwirausaha dan motivasi berwirausaha rendah. Penelitian ini bertujuan untuk mengetahui Pengaruh Mental Berwirausaha dan Modal Berwirasuaha Terhadap Minat Berwirausaha dengan Motivasi Berwirausaha Sebagai Variabel Intervening Pada Mahasiswa Program Studi Pendidikan Ekonomi Fakultas Ekonomi Universitas Negeri Medan Stambuk 2017. Populasi dalam penelitian ini adalah seluruh Mahasiswa Prodi Pendidikan Ekonomi Stambuk 2017 Fakultas Ekonomi Universitas Negeri Medan yang terdiri dari tiga kelas yaitu kelas Pendidikan Ekonomi A, B dan C dengan jumlah 113 mahasiswa. Pengambilan sampel menggunakan rumus slovin dengan jumlah sampel yaitu 88 mahasiswa. Teknik pengumpulan data yang digunakan adalah wawancara, observasi, dokumentasi dan kuesioner. Teknik analisis data yang digunakan adalah Regresi Linear berganda dan Analisis Jalur, untuk menguji hipotesis digunakan Uji t (parsial), Uji F, dan Koefisien Determinasi (R2). Hasil penelitian menunjukkan bahwa : (1) Terdapat pengaruh yang positif dan signifikan antara mental berwirausaha dan modal berwirausaha terhadap minat berwirausaha. (2) Terdapat pengaruh yang positif dan signifikan antara mental berwirausaha, modal berwirausaha, dan minat berwirausaha terhadap motivasi berwirausaha.
\end{abstract}

Kata Kunci: Mental Berwirausaha, Modal Berwirausaha, Minat Berwirausaha, Motivasi Berwirausaha 


\section{PENDAHULUAN}

Permasalahan pengangguran dan kemiskinan yang masih sering terjadi dan menjadi masalah besar yang harus dihadapi oleh bangsa Indonesia. Semakin banyak penduduk Indonesia yang tiap tahunnya terjun ke dunia kerja menjadikan tantangan yang besar bagi pemerintah Indonesia, di sisi lain sedikitnya lapangan pekerjaan tidak dapat menampung banyaknya masyarakat yang ingin bekerja. Hal ini tentu menjadi masalah dan tugas yang perlu ditangani oleh pemerintah Indonesia. Sebagai warga negara yang baik, maka haruslah juga ikut berpartisipasi dalam menangani masalah pengangguran tersebut bersama-sama dengan pemerintah. Salah satu caranya adalah dengan bukan hanya dengan mencari pekerjaan tetapi menciptakan pekerjaan atau dengan kata lain yaitu berwirausaha.

Berwirausaha merupakan suatu kegiatan menciptakan atau menjalani suatu usaha atau bisnis yang bisa menghasilkan pendapatan. Berwirausaha merupakan satu kata yang memiliki proses panjang untuk dapat melakukannya, karena diperlukan kolaborasi dari banyak faktor yang mendukung agar seseorang dapat mulai berwirausaha. Namun terlepas dari itu semua, hal yang terpenting yang harus diperhatikan adalah keberanian untuk memulai suatu usaha yang diawali dengan memiliki minat berwirausaha.

Minat dapat diartikan sebagai rasa senang atau ketertarikan terhadap sesuatu. Kemudian, menurut Fadli (2009:93) minat berwirausaha merupakan suatu ketertarikan, keinginan dan ketersediaan seseorang melalui ide dan inovasi yang dimiliki untuk bekerja keras untuk memenuhi kebutuhan hidupnya tanpa rasa takut dengan risiko yang akan terjadi, dapat menerima tantangan, percaya diri, kreatif dan inovatif, serta memiliki kemampuan dalam memenuhi kebutuhannya. Minat menjadi wirausaha didefinisikan sebagai keinginan seseorang untuk bekerja mandiri atau menjalankan usahanya sendiri. Minat untuk mulai berwirausaha pada mahasiswa sebenarnya sudah cukup tinggi, namun bayangan kegagalan, tidak memiliki modal yang cukup dan tidak memiliki waktu untuk fokus dalam mengembangkan usahanya menjadi risiko yang menghambat mahasiswa untuk memulai usahanya sendiri.
Berdasarkan sebaran angket tetap dan hasil wawancara yang peneliti lakukan dengan mahasiswa Pendidikan Ekonomi Fakultas Ekonomi Universitas Negeri Medan Stambuk 2017 menunjukkan bahwa 52 \% Mahasiswa Pendidikan Ekonomi Fakultas Ekonomi Universitas Negeri Medan Stambuk 2017 kurang memiliki minat terhadap wirausaha, dan hanya sebesar $48 \%$ mahasiswa sajalah yang masih memiliki minat berwirausaha.

Faktor yang mempengaruhi minat berwirausaha, seperti yang dikutip dari Bygrave (2011:23) mengatakan salah satunya adalah faktor personal yaitu mental. Mental yang dimaksud disini adalah kesiapan diri dalam menghadapi segala tantangan dan resiko yang akan terjadi saat seseorang memutuskan untuk mulai berwirausaha. Apabila seseorang sudah memiliki mental yang kuat untuk berwirausaha maka ia pasti memiliki minat yang kuat dalam berwirausaha. Jadi bisa dikatakan bahwa mental berpengaruh terhadap minat berwirausaha.

Selain itu, menurut Bygrave (2011:40) mengatakan bahwasanya faktor yang mempengaruhi minat berwirausaha lainnya adalah adanya sumber-sumber yang bisa dimanfaatkan seperti modal, tabungan, warisan, bangunan, dan lokasi strategis. Modal usaha merupakan salah satu faktor yang mempengaruhi minat seseorang berwirausaha . Modal ini dapat berupa uang ataupunbarang apa saja yang bisa digunakan untuk membuka suatu usaha. Dengan adanya modal usaha maka ia bisa membeli apapun yang ia butuhkan untuk membuka usaha. Karena adanya modal yang membuat seseorang bisa membeli apapun yang ia butuhkan untuk membuka usaha maka orang yang memiliki modal usaha cenderung akan lebih berminat berwirausaha daripada orang yang tidak memiliki modal usaha

Selain mempengaruhi minat berusaha secara langsung. Mental juga ternyata berpengaruh terhadap motivasi seseorang dalam berwirausaha. Menurut Uno (2004:7) motivasi dibedakan menjadi dua macam, yaitu: motivasi intrinsik dan motivasi ekstrinsik. Salah satu motivasi intrinsik dalam motivasi berwirausaha adalah mental berwirausaha. Mental merupakan sikap dalam diri seseorang yang mempengaruhi dirinya dalam melakukan sesuatu. Mental yang kuat merupakan salah satu contoh jenis motivasi yang berasal dari 
dalam diri . Dengan adanya mental yang kuat dalam diri seseorang maka ia pasti sanggup menghadapi segala masalah dan resiko. Jadi bisa dikatakan bahwa seseorang yang memiliki mental berwirausaha akan memiliki motivasi yang tinggi dalam berwirausaha

Berdasarkan wawancara dengan mahasiswa pendidikan ekonomi stambuk 2017, sebagian besar diantara mereka tidak siap untuk memulai berwirusaha karena mereka takut dan tidak yakin jika mereka akan berhasil. Beberapa diantara mereka juga mengatakan bahwa berwirausaha adalah hal yang merepotkan karena mereka akan terbebani dan sehingga tidak bisa fokus untuk kuliah.

Selain itu dari hasil wawancara banyak mahasiswa tidak memiliki motivasi untuk berwirausaha sehingga mereka tidak berminat untuk berwirausaha. Padahal seharusnya para mahasiswa sudah memiliki motivasi tersebut dan mentalnya sudah terlatih dengan baik pada saat duduk di bangku perkuliahan, dimana mahasiswa di didik selama 4 tahun untuk bisa menjadi manusia yang berkualitas saat kelak barada di masyarakat. Sehingga saat mahasiswa itu lulus diharapan mereka bisa membuka lapangan pekerjaan sendiri, karena selama 4 tahun ia di bangku perkulihan sudah dibekali dengan banyak ilmu yang bisa ia pergunakan untuk memulai berwirausaha.

Berdasarkan observasi pada mahasiswa pendidikan ekonomi stambuk 2017, peneliti melihat fakta dimana sangat sedikit sekali mahasiswa yang memiliki usaha sendiri, dikarenakan untuk membiayai hidupnya mereka hanya berharap kepada uang bulanan yang dikirim oleh orang tua mereka, selain itu kegiatan sebahagian besar mahasiswa di fakultas ekonomi Unimed hanya fokus pada kegiatan perkuliahan dan mengerjakan tugas. Berdasarkan fakta fakta tersebut diatas yang diperoleh dari hasil observasi pada mahasiswa pendidikan ekonomi stambuk 2017 Universitas Negeri Medan, peneliti merasa penelitian ini penting untuk dilakukan karena melihat lebih dari setengah dari jumlah Mahasiswa Pendidikan Ekonomi Fakultas Ekonomi Universitas Negeri Medan Stambuk 2017 tidak memiliki minat berwirausaha, jadi perlu diteliti lebih lanjut variabel variabel apakah yang menjadi penyebabnya.

\section{TINJAUAN PUSTAKA \\ Mental Berwirausaha}

Menurut Suryana (2015:55) Mental adalah hal-hal yang berkaitan dengan kejiwaan yang dapat mempengaruhi perilaku individu Manusia yang bermental wirausaha mempunyai kemauan keras untuk mencapai tujuan dan kebutuhan hidupnya.

Menurut Martinis (2015:87) Mental bewirausaha berarti kecenderungan pribadi/jiwa seseorang yang membuahkan tindakan/tingkah laku, baik sebagai wirausaha atau potensi menjadi wirausaha.

Mental berwirausaha adalah sikap seseorang yang memiliki rasa tanggung jawab, selalu dinamis, ulet dan gigih. Menurut Sudantoko (2015:34) Seorang wirausaha harus memiliki sikap mental yang berani menerima kritik saran yang bermanfaat serta berinisiatif untuk maju dan melakukan yang terbaik untuk mencapai keberhasilan.

Menurut Hantoro (2015:28) secara global dapat dikatakan bahwa seorang yang memiliki sikap mental berwirausaha setidaktidaknya memiliki beberapa kriteria sebagai berikut :
a. Berkemauan keras dan pantang menyerah
b. Berkeyakinan kuat atas kekuatan pribadi
c. Jujur dan bertanggungjawab
d. Ketahanan fisik dan mental

\section{Modal Berwirausaha}

Modal adalah pokok utama dalam menjalankan suatu bisnis atau usaha, modal faktor penting dalam menjalankan usahanya, karena modal salah satu unsur dimana perusahaan dapat menjalankan usahanya dan mendapatkan keuntungan. Menurut Munawir (2014:19) mengatakan bahwa modal adalah hak atau bagian yang dimiliki oleh pemilik perusahaan yang ditujukan dalam pos modal (modal saham), surplus dan laba yang ditahan atau kelebihan nilai aktiva yang dimiliki oleh perusahaan terhadap seluruh hutanghutangnya".

Menurut Tambunan (2017:76), "Modal adalah semua bentuk kekayaan yang dapat digunakan langsung maupun tidak langsung dalam proses produksi untuk menambah output".

Berdasarkan beberapa pendapat ahli diatas modal adalah bentuk kekayaan yang dapat digunakan langsung maupun tidak langsung 
dalam proses produksi untuk menambah output atau dapat juga disebut kelebihan nilai aktiva yang dimiliki oleh perusahaan terhadap seluruh hutang-hutangnya

Adapun Macam-Macam Modal yaitu sebagai berikut :

1. Modal Sendiri

Menurut Mardiyatmo (2018:23) "Modal sendiri adalah modal yang diperoleh dari pemilik usaha itu sendiri.Modal sendiri terdiri dari tabungan, sumbangan, hibah, saudara, dan lain sebagainya".

2. Modal Asing (Pinjaman)

Modal asing atau modal pinjaman adalah modal yang biasanya diperoleh dari pihak luar perusahaan dan biasanya diperoleh dari pinjaman. Keuntungan modal pinjaman adalah jumlahnya yang tidak terbatas, artinya tersedia dalam jumlah banyak. Di samping itu, dengan menggunakan modal pinjaman biasanya timbul motivasi dari pihak manajemen untuk mengerjakan usaha dengan sungguh-sungguh.

\section{Modal Patungan}

Menurut Kasmir (2016:54), Selain modal sendiri atau pinjaman, juga bisa menggunakan modal usaha dengan cara berbagai kepemilikan usaha dengan orang lain. Caranya dengan menggabungkan antara modal sendiri dengan modal satu orang teman atau beberapa orang yang berperan sebagai mitra usaha

\section{Motivasi Wirausaha}

Ketika manusia akan melakukan suatu kegiatan akan dipengaruhi oleh suatu kondisi psikologis yang mendorongnya untuk melakukan kegiatan tersebut. Kondisi psikologis tersebut dapat berasal dari dalam maupun luar tubuh manusia dan memberikan dampak yang cukup besar terhadap keberhasilan dari suatu kegiatan.Kondisi psikologis atau dorongan tersebut dinamakan motivasi.

Menurut Gerungan (2015:99), motivasi merupakan dorongan dalam diri manusia yang menyebabkan manusia tersebut melakukan sesuatu atau kegiatan.

Menurut Uno (2018:3) motivasi adalah dorongan dasar yang menggerakkan seseorang untuk bertingkah laku. Selain itu Uno juga menjelaskan bahwa motivasi adalah kekuatan, baik dari dalam atau luar tubuh manusia yang mendorong untuk mencapai tujuan tertentu yang telah ditetapkan sebelumnya.
Menurut Pitriasari (2016:36), "Wirausaha pada hakikatnya adalah suatu kemampuan seseorang untuk melihat dan menilai kesempatan-kesempatan bisnis, mengumpulkan sumber-sumber daya yang dibutuhkan guna mengambil keuntungan dari padanya dan mengambil tindakan yang tepat guna memastikan sukses". Sejalan dengan itu menurut Nitisusastro (2016:26), "wirausaha merupakan seseorang yang mengorganisasikan, mengoperasikan dan memperhitungkan risiko untuk sebuah usaha yang mendatangkan laba".

Dari beberapa pendapat ahli diatas dapat disimpulkan bahwa wirausaha adalah suatu kemampuan seseorang untuk melihat dan menilai kesempatan-kesempatan bisnis, mengorganisasikan, mengoperasikan dan memperhitungkan risiko untuk sebuah usaha yang mendatangkan laba.

Faktor - Faktor yang Mempengaruhi Motivasi Berwirausaha menurut Saiman (2019:26) mengemukakan, ada empat faktor motivasi seseorang untuk berwirausaha, yaitu sebagai berikut:

1. Laba

Dapat menentukan berapa laba yang dikehendaki, keuntungan yang diterima, dan berapa yang akan dibayarkan kepada pihak lain atau pegawainya.

2. Kebebasan

Bebas mengatur waktu, bebas dari supervisor, bebas dari aturan yang menekan, dan bebas dari budaya organisasi/perusahaan.

3. Impian Personal

Bebas mencapai standar hidup yang diharapkan, lepas dari rutinitas kerja yang berulang-ulang, karena harus mengikuti visi, misi, impian orang lain.

4. Kemandirian

Memiliki rasa bangga, karena dapat mandiri dalam segala hal, seperti permodalan, mandiri dalam pengelolaan atau manajemen, mandiri dalam pengawasan, serta menjadi manajer terhadap dirinya sendiri.

\section{Minat Berwirausaha}

Menurut Winkel (2016:30), minat adalah kecenderungan yang akan menetap dalam subjek merasa tertarik pada bidang/hal tertentu dan merasa senang berkecimpung dalam bidang itu". 
Sejalan dengan teori diatas, menurut Slameto (2015:57), minat adalah kecenderungan yang tetap untuk memperhatikan dan mengenang beberapa kegiatan. Sejalan dengan itu menurut Suryabrata (2018:109), Minat adalah "kecenderungan dalam diri individu untuk tertarik pada sesuatu objek atau menyenangi sesuatu objek.

\section{METODE PENELITIAN}

\section{Lokasi dan Waktu Penelitian}

Lokasi penelitian dilaksanakan di Fakultas Ekonomi Universitas Negeri Medan. Penelitian ini dilaksanakan pada semester ganjil tahun pelajaran 2019/2020.

\section{Populasi dan Sampel Penelitian}

Populasi pada penelitian ini adalah seluruh Mahasiswa Prodi Pendidikan Ekonomi Stambuk 2017 Fakultas Ekonomi Universitas Negeri Medan yang terdiri dari 3 kelas yaitu kelas Pendidikan Ekonomi A,B dan C yaitu sebanyak 113 siswa. Sampel dalam penelitian ini adalah berjumlah 88 orang dengan menggunakan rumus slovin dan teknik pengambilan sampel yaitu Proporsional random sampling

\section{Teknik Pengumpulan Data}

Teknik pengumpulan data dalam penelitian ini adalah dengan cara observasi, wawancara, dokumentasi, dan penyebaran angket.

\section{Teknik Analisis Data}

\section{Uji Instrumen}

Uji intrumen dalam penelitian ini menggunakan uji validitas dan uji reliabilitas terhadap angket.

Uji Validitas pada pnelitian ini menggunakan rumus korelasi Produk Moment

$$
r_{x y}=\frac{N \sum(X Y)-\sum(X)\left(\sum(Y)\right.}{\sqrt{\left\{N \sum X^{2}-\left(\sum X\right)^{2}\right\}}}
$$

(Arikunto, $2014: 37$ )

$\mathrm{r}^{\mathrm{xy}} \quad=$ Koefisien korelasi antara variabel $\mathrm{x}$ dan y

$\sum \mathrm{X}=$ Jumlah skor variabel $\mathrm{X}$

$\sum \mathrm{Y}=$ Jumlah skor variabel $\mathrm{Y}$

$\sum X Y=$ Jumlah skor variabel $\mathrm{XY}$ $\sum \mathrm{X}^{2} \quad=$ Jumlah skor variabel $\mathrm{X}^{2}$

$\sum \mathrm{Y}^{2}=$ Jumlah skor variabel $\mathrm{Y}^{2}$

$\mathrm{N} \quad=$ Jumlah responden atau banyaknya sampel

Syarat valid apabila $r_{\text {hitung }}>r_{\text {tabel }}$ dengan taraf signifikan 95\% ( $\alpha=5 \%)$ maka instrument itu dianggap valid dan jika $\mathrm{r}_{\text {hitung }}<\mathrm{r}_{\text {tabel }}$ pada taraf signifikan $95 \%(\alpha=5 \%)$ maka instrument tersebut dianggap tidak valid.

Untuk menguji reliabilitas instrument dapat dihitung dengan menggunakan rumus alpha, seperti yang dikemukakan Arikunto (2014: 37) :

$$
r_{11}=\left[\frac{k}{k-1}\right]\left[1-\frac{\sum \sigma_{b}^{2}}{\sigma_{t}^{2}}\right]
$$

Keterangan :

$\mathrm{r} 11=$ Reliabilitas instrumen

$\mathrm{k} \quad=$ Banyaknya butir pertanyaan atau banyaknya soal

$\sum \sigma_{b}^{2}=$ Jumlah varians butir

$\sum \sigma_{t}^{2}=$ varians total

Untuk mencari varians butir soal digunakan rumus:

$$
\sigma_{b}^{2}=\frac{\sum x^{2}-\left(\frac{\sum x}{N}\right)^{2}}{N}
$$

Keterangan :

$\mathrm{N} \quad=$ Jumlah responden

$\sum \mathrm{X}=$ Jumlah skor variabel $\mathrm{X}$

$\sum \mathrm{X}^{2} \quad$ Jumlah skor kuadrat variabel $\mathrm{X}$

Untuk mencari varians total digunakan rumus:

$$
\sigma_{t}^{2}=\frac{\sum Y^{2}-\left(\frac{\sum Y}{N}\right)^{2}}{N}
$$

Keterangan :

$\mathrm{N}=$ Jumlah responden/sampel

$\sum \mathrm{Y}=$ Banyaknya skor total subjek

$\sum \mathrm{Y}^{2} \quad=$ Jumlah skor kuadrat skor total subjek

Dengan ketentuan jika $r_{\text {hitung }}>r_{\text {tabel }}$ signifikan 95\% ( $\alpha=5 \%)$ maka dapat dikatakan reliabel, selanjutnya jika $\mathrm{r}_{\text {hitung }} \leq \mathrm{r}_{\text {tabel }}$, maka instrument dianggap tidak reliabel.

\section{Uji Asumsi Klasik \\ a. Uji Normalitas}

Uji Normalitas yang dilakukan dengan analisis grafik yang dideteksi dengan melihat penyebaran data (titik) pada sumbu diagonal 
grafik atau dengan melihat histogram dari residualnya.

Untuk mendeteksi normalitas dari data dapat dilihat dari titik-titik yang tersebar di sekitar garis diagonal. Semakin dekat dengan garis diagonal berarti data berdistribusi normal, dan sebaliknya. Cara yang kedua adalah melalui uji One Sample Kolmogorof-Smirnov (K-S), dengan dasar pengambilan keputusan yakni, jika hasil uji Kolmogrov-Smirnov menunjukkan nilai signifikansi di atas $5 \%(\alpha=$ $0,05)$ maka data residual terdistribusi dengan normal (nilai probabilitas $\alpha>0,05$ ). Sedangkan jika hasil uji Kolmogrov-Smirnov menunjukkan nilai signifikansi di bawah $5 \%(\alpha$ $=0,05)$ maka data residual terdistribusi tidak normal (nilai probabilitas $\leq 0,05$ ). Pengolahan uji normalitas dengan menggunakan bantuan program SPSS.

\section{b. Uji Linieritas}

Uji Linearitas dimaksudkan untuk mengetahui apakah variabel bebas (X) dan variabel terikat $(\mathrm{Y})$ berbentuk linear atau tidak. Uji linearitas merupakan uji persyaratan yang biasanya dilakukan jika akan melakukan analisis regresi linear.

Dasar pengambilan keputusan dalam uji linearitas dapat dilakukan dengan dua cara, yaitu :

1. Dengan melihat nilai signifikansi nya, jika nilai signifikasi $\geq 0,05$ maka dapat disimpulkan bahwa terdapat hubungan linear secara signifikan antara variable $\mathrm{X}$ dengan Variabel Y. Sebaliknya, jika nilai signifikansi $\leq 0,05$ maka tidak terdapat hubungan yang linear antara variable $\mathrm{X}$ dengan variable $\mathrm{Y}$.

2. Dengan melihat nilai $\mathrm{F}$ hitung dan $\mathrm{F}$ tabel, jika $\mathrm{F}$ hitung $\leq \mathrm{F}$ tabel, maka terdapat hubungan linear secara signifikan antara variable X dan Variabel Y. Sebaliknya, jika nilai $\mathrm{F}$ hitung $\geq \mathrm{F}$ tabel maka tidak terdapat hubungan linear antara variable $\mathrm{X}$ dan Variable Y. Data di olah menggunakan program SPSS 21

\section{c. Uji Multikolinieritas}

Uji multikolinieritas bertujuan untuk menguji apakah pada model regresi ditemukan adanya korelasi antar variabel bebas. Model regresi yang baik seharusnya tidak terjadi multikolinearitas. Suatu model regresi dikatakan tidak terjadi multikolinearitas apabila nilai Varians Inflation Factor (VIF) <
10 dan nilai Tolerance> 0,1. Dalam pengolahannya penulis meggunakan bantuan program IBM SPSS Statistic 20.

\section{Analisis Regresi Linier Berganda}

Data yang diperoleh akan dianalisis dengan menggunakan statistik korelasi. Ada 2 persamaan regresi linear berganda, yang pertama adalah untuk mengetahui bagaimana hubungan antara kedua variabel bebas $\mathrm{X}_{1}$ (Mental Berwirausaha) dan $\mathrm{X}_{2}$ (Modal Berwirausaha) terhadap variabel terikat $\mathrm{Y}$ (Minat Berwirausaha) dan persamaan yang kedua adalah untuk mengetahui bagaimana hubungan antara ketiga variabel bebas X1 (Mental Berwirausaha) dan X2 (Modal Berwirausaha) dan $\mathrm{X}_{3} / \mathrm{Y}_{1}$ (Minat Berwirausaha) terhadap variabel terikat $\mathrm{Y}_{2}$ (Motivasi Berwirausaha) dapat digunakan rumus analisis Regresi Linear Berganda oleh Arikunto (2014:344) sebagai berikut:

Persamaan 1 :

$Y=\hat{\mathrm{a}}_{0}+\mathrm{a}_{1} X_{1}+\hat{\mathrm{a}}_{2} X_{2}+e$

Persamaan 2:

$Y_{2}=\hat{\mathrm{a}}_{0}+\hat{\mathrm{a}}_{1} X_{1}+\hat{\mathrm{a}}_{2} Y_{1}+e$

Untuk mempermudah perhitungan maka peneliti dibantu dengan program SPSS 20.

\section{Analisis Jalur}

Analisis jalur adalah bagian dari model regresi yang dapat digunakan untuk menganalisis hubungan sebab akibat antar satu variabel dengan variabel lainnya. Menurut Sugiyono (2016:70) Analisis jalur digunakan dengan menggunakan korelasi, regresi dan jalur sehingga dapat diketahui untuk sampai pada variabel dependen terakhir, harus lewat jalur langsung atau melalui variabel intervening

Langkah berikutnya yang harus dikerjakan sebelum melakukan analisis jalur adalah merancang diagram jalur sesuai dengan hipotesis yang dikembangkan dalam penelitian. Model diagram jalur dibuat berdasarkan variabel-variabel yang dikaji, dalam penelitian ini variabel yang dikaji adalah Mental (X1), Modal (X2), Minat berwirausaha (Y) dan Motivasi Berwirausaha( Z).

Persamaan model ini terdiri dari dua tahap :

Tahap 1: $\mathrm{Y} 1=\mathrm{b} 1 \mathrm{X} 1+\mathrm{b} 2 \mathrm{X} 2+\mathrm{b} 3 \mathrm{X} 3+\mathrm{e} 1$ Tahap 2: Y2= b1 X1 + b2 X2+ b3 X3 + b4 X4 $+\mathrm{e} 2$ 
Analisis jalur (Path analysis) dalam penelitian ini adalah kepuasan pelanggan Analisis jalur akan membantu dalam melihat besarnya koefisien secara langsung dan tidak langsung dari variabel terikat terhadap variabel bebas, dengan memperhatikan besarnya koefisien. maka bisa di bandingkan besarnya pengaruh secara langsung dan tidak langsung.

\section{Uji Hipotesis}

Pengujian Hipotesis Secara Parsial (Uji t) dalam penelitian ini menggunakan rumus:

$$
\boldsymbol{t}_{\text {regrest }}=\frac{\boldsymbol{b}_{i}-\boldsymbol{\beta}_{i}}{S b i}
$$

Keterangan:

$b_{i} \quad=$ koefisien regresi variabel

$\mathrm{Sb}_{\mathrm{i}} \quad=$ Standar error/kesalahan standar koefisien regresi variabel $\left(b_{i}\right)$

$\beta \mathrm{i}=$ koefisien beta/parameter ke-I dihipotesiskan

Sedangkan pengujian hipotesis secara simultan (Uji $\mathrm{F})$ dalam penelitian ini menggunakan:

$$
\boldsymbol{F}_{h}=\frac{\boldsymbol{R}^{2 / k}}{\left(1-\boldsymbol{R}^{2}\right) /(n-k-1)}
$$

Keterangan:

$$
\begin{array}{ll}
\mathrm{R} & =\text { koefisien determinasi } \\
\mathrm{k} & =\text { jumlah variabel independen } \\
\mathrm{n} & =\text { jumlah anggota sampel }
\end{array}
$$

\section{Koefisien Determinasi $\left(\mathbf{R}^{2}\right)$}

Koefesien determinasi (R2) pada intinya mengukur seberapa jauh kemampuan model dalam menerangkan variasi variabel dependen"

Nilai koefisien determinasi adalah 0-1 (nilainya berkisaran antara $0<\mathrm{R} 2<1$ ), dengan kriteria sebagai berikut:

1. Jika R2 mendekati 0, maka variabel independen dan variabel dependen tidak ada keterkaitan.

2. Jika R2 mendekati 1, maka diantara variabel independen dan variabel dependen ada keterkaitan.

\section{HASIL DAN PEMBAHASAN}

\section{Hasil Uji Analisis Regresi Linear Berganda (Persamaan 2)}

Dari hasil pengolahan data maka dibuat persamaan regresi sebagai berikut :

$\mathrm{Y}=\mathrm{a} 0+\mathrm{a} 1 \mathrm{X} 1+\mathrm{a} 2 \mathrm{X} 2+\mathrm{a} 3 \mathrm{X} 3 \mathrm{e}$
$\mathrm{Y}=42,569+0,236 \mathrm{X} 1+0,361 \mathrm{X} 2+0,599 \mathrm{X} 3+\mathrm{e}$ Penjelasan persamaan tersebut sebagai berikut

a. Nilai Konstanta (a) sebesar 42,569 artinya jika variabel mental berwirausaha (X_1), modal berwirausaha (X_2) dan minat berwirausaha $(\mathrm{Z} / \mathrm{X} 3)$ nilainya nol, maka motivasi berwirausaha (Y) konstan 42,569 .

b. Nilai Koefisien regresi variabel mental berwirausaha (a1) sebesar 0,236 artinya jika mental berwirausaha mengalami kenaikan satu persen, maka motivasi berwirausaha secara rata-rata akan mengalami peningkatan sebesar $0,236 \%$ dengan asumsi variabel independen lainnya tetap.

c. Nilai Koefisien regresi variabel modal berwirausaha (a2) sebesar 0,361 artinya jika modal berwirausaha mengalami kenaikan satu persen, maka motivasi berwirausaha secara rata-rata akan mengalami peningkatan sebesar $0,361 \%$ dengan asumsi variabel independen lainnya tetap.

d. Nilai Koefisien regresi variabel minat berwirausaha (a3) sebesar 0,599 artinya jika minat berwirausaha mengalami kenaikan satu persen, maka motivasi berwirausaha secara rata-rata akan mengalami peningkatan sebesar 0,599\% dengan asumsi variabel independen lainnya tetap

\section{Analisis Jalur}

Analisis jalur adalah bagian dari model regresi yang dapat digunakan untuk menganalisis hubungan akibat antar satu variabel dengan variabel lainnya. Dalam analisis jalur pengaruh variabel independen terhadap variabel dependen dapat berupa pengaruh langsung dan tidak langsung (direct and direct effect), atau dengan kata lain analisis jalur memperhitungkan adanya pengaruh langsung dan tidak langsung

1. Analisis Pengaruh Langsung (Direct Effect)

a. Pengaruh variabel Mental Berwirausaha Terhadap Minat Berwirausaha

$\mathrm{X} 1(\mathrm{Rho1}) \rightarrow \mathrm{Y}=0,416$

Maka Besarnya pengaruh langsung X1

(Rho1) terhadap Y adalah 0,410 
b. Pengaruh variabel Modal Berwirausaha Terhadap Minat Berwirausaha X2 (Rho2) $\rightarrow \mathrm{Y}=0,431$

Maka Besarnya pengaruh langsung X2 (Rho2) terhadap Y adalah 0,431

c. Pengaruh variabel Mental Berwirausaha Terhadap Motivasi Berwirausaha

$\mathrm{X} 1(\mathrm{Rho1}) \rightarrow \mathrm{Y} 2=0,355$

Maka Besarnya pengaruh langsung X1 (Rho1) terhadap Y2 adalah 0,355

d. Pengaruh variabel Modal Berwirausaha Terhadap Motivasi Berwirausaha $\mathrm{X} 2$ (Rho2) $\rightarrow \mathrm{Y} 2=0,421$

Maka Besarnya pengaruh langsung X2 (Rho2) terhadap Y2 adalah 0,421

e. Pengaruh variabel Minat Berwirausaha Terhadap Motivasi Berwirausaha

$\mathrm{M}(\mathrm{Y} 2) \rightarrow \mathrm{Y}=0,534$

Maka Besarnya pengaruh langsung M (Y2) terhadap Y adalah 0,534

2. Analisis Pengaruh Tidak Langsung (Indirrect Effect)

a. Pengaruh Variabel Mental Berwirausaha terhadap Minat Berwirausaha Melalui Motivasi Berwirausaha X1 (Rho1) $\rightarrow$ M $\rightarrow Y=0,416$ x $0,534=0,222$. Maka Besarnya Pengaruh tidak langsung Variabel Mental Berwirausaha terhadap Minat Berwirausaha dimediasi Motivasi Berwirausaha adalah 0,222

b. Pengaruh Variabel Modal Berwirausaha terhadap Minat Berwirausaha Melalui Motivasi Berwirausaha

$\mathrm{X} 2(\mathrm{Rho} 2) \rightarrow \mathrm{M} \rightarrow \mathrm{Y}=0,431 \times 0,534=$ 0,230 Maka Besarnya Pengaruh tidak langsung Variabel Modal Berwirausaha terhadap Minat Berwirausaha dimediasi Motivasi Berwirausaha adalah 0,230

3. Analisis Pengaruh Total (Total Effect)

a. Pengaruh Variabel Mental Berwirausaha terhadap Minat Berwirausaha Melalui Motivasi Berwirausaha X1 (Rho1) $\rightarrow$ M $\rightarrow \mathrm{Y}=0,355+0,222=0,577$ Maka Besarnya Pengaruh Total Variabel Mental Berwirausaha terhadap Minat Berwirausaha dimediasi Motivasi Berwirausaha adalah 0,577

b. Pengaruh Variabel Modal Berwirausaha terhadap Minat Berwirausaha Melalui Motivasi Berwirausaha X2 (Rho2) $\rightarrow$ M $\rightarrow \mathrm{Y}=0,421+0,230=0,651$ Maka Besarnya Pengaruh Total Variabel Modal Berwirausaha terhadap Minat Berwirausaha dimediasi Motivasi Berwirausaha adalah 0,651

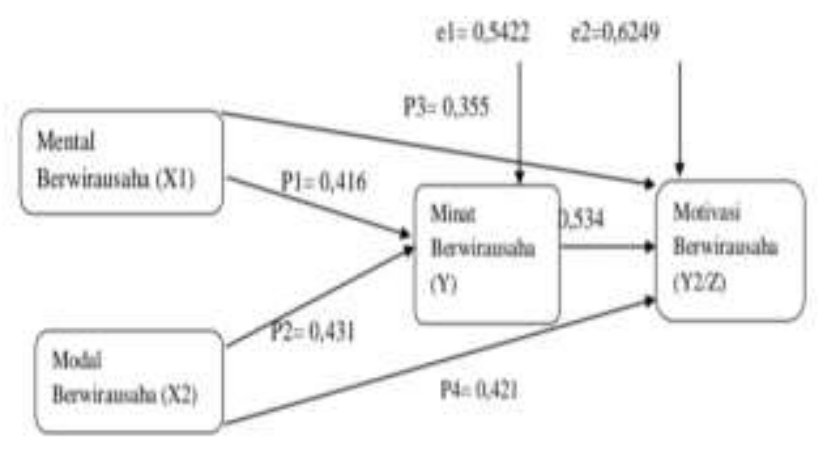

Gambar 1. Diagram jalur persamaan 2

Dari pembahasan diatas, maka dapat disimpulkan hipotesis "Ada pengaruh positif dan signifikan antara mental dan modal terhadap minat berwirausaha dengan motivasi wirausaha sebagai variabel intervening pada mahasiswa Program Studi Pendidikan Ekonomi Fakultas Ekonomi Universitas Negeri Medan Stambuk 2017" dapat diterima.

\section{Uji Hipotesis}

\section{a. Uji t Parsial}

Hasil perhitungan uji hipotesis secara parsial (Uji t) pada Variabel Mental Berwirausaha (X1) Terhadap Minat Berwirausaha diperoleh t-hitung $=2,868$ pada taraf signifikan $\alpha=5 \%$ nilai t-tabel 1,988 hasil ini didapat bahwa t-hitung > t-tabel $(2,868>1,988)$, dilihat dari nilai sig $<0,05$ atau $0,006<0,05$. Maka dapat disimpulkan bahwa variabel mental berwirausaha secara parsial berpengaruh secara positif dan signifikan terhadap minat berwirausaha.

Hasil perhitungan uji hipotesis secara parsial (Uji t) pada Variabel Modal Berwirausaha (X1) Terhadap Minat diperoleh $\mathrm{t}$-hitung=2,973 . Sedangkan nilai t-tabel pada taraf signifikan $\alpha=5 \%$ sebesar 1,988 dari hasil ini didapat bahwa t-hitung $>$ t-tabel $(2,973>1,988)$, dilihat nilai sig $<0,05$ atau $0,004<0,05$ Maka dapat disimpulkan bahwa variabel modal kewirausahaan secara parsial 
berpengaruh secara positif dan signifikan terhadap minat berwirausaha diterima.

Hasil perhitungan uji hipotesis secara

parsial (Uji t) pada Variabel Mental Berwirausaha (X1) Terhadap Motivasi Berwirausaha diperoleh $\mathrm{t}$-hitung $=2,983$. Sedangkan nilai t-tabel pada taraf signifikan $\alpha$ $=5 \%$ sebesar 1,988 dari hasil ini didapat bahwa t-hitung $>$ t-tabel $(2,983>1,988)$, dilihat nilai sig <0,05 atau 0,004 <0,05 Maka dapat disimpulkan bahwa variabel mental kewirausahaan secara parsial berpengaruh secara positif dan signifikan terhadap motivasi berwirausaha diterima.

Hasil perhitungan uji hipotesis secara parsial (Uji t) pada Variabel Modal Berwirausaha (X1) Terhadap Motivasi diperoleh t-hitung $=3,621$ sedangkan nilai ttabel pada taraf signifikan $\alpha=5 \%$ sebesar 1,988 dari hasil ini didapat bahwa t-hitung $>\mathrm{t}$ tabel $(3,621>1,988)$, dilihat nilai sig $<0,05$ atau $0,000<0,05$ Maka dapat disimpulkan bahwa variabel modal kewirausahaan secara parsial berpengaruh secara positif dan signifikan terhadap motivasi berwirausaha diterima.

\section{b. Uji Simultan (uji F)}

\section{Hasil Perhitungan Hipotesis Secara Simultan (Uji F) (Persamaan 1)}

Berdasarkan hasil pengolahan data dengan menggunakan program SPSS 20 diperoleh F-hitung $=69,280$. Sedangkan nilai F-tabel dengan tingkat signifikansi 5\% hasil diperoleh untuk F tabel sebesar 3,10 . Dari hasil perhitungan diperoleh F-hitung sebesar $69,280>3,10$ dapat disimpulkan bahwa variabel mental berwirausaha (X_1) dan variabel modal berwirausaha (X_2) secara bersama-sama berpengaruh positif dan signifikan terhadap minat berwirausaha $(\mathrm{Y})$.

\section{Hasil Perhitungan Hipotesis Secara Simultan (Uji F) (Persamaan 2)}

Berdasarkan hasil pengolahan data dengan menggunakan program SPSS 20 diperoleh F-hitung $=67,438$. Sedangkan nilai F-tabel dengan tingkat signifiknasi 5\%, diperoleh untuk $\mathrm{F}$ tabel sebesar 2,71 . Dari hasil perhitungan diperoleh F-hitung sebesar $67,438>2,71$ dapat disimpulkan bahwa variabel mental berwirausaha (X_1), variabel modal berwirausaha (X_2) dan minat berwirausaha (Y) secara bersama-sama berpengaruh positif dan signifikan terhadap motivasi berwirausaha (Y2).

\section{c. Koefisien Determinasi $\left(\mathbf{R}^{2}\right)$}

Uji koefisien determinasi $\left(\mathrm{R}^{2}\right)$ digunakan untuk mengetahui bagaimana kontribusi atau kemampuan variabel bebas dalam menerangkan variabel terikat.

Hasil Koefisien Determinasi (R2) (Persamaan 1) nilai R Square sebesar 0,706 atau 70,6\%. Hal ini menunjukkan bahwa persentase sumbangan pengaruh variabel independen, yaitu mental berwirausaha (X1) dan modal berwirausaha (X2) terhadap variabel dependen yaitu minat berwirausaha (Y) sebesar 70,6\% sedangkan sisanya $29,4 \%$ dipengaruhi oleh variabel lain yang tidak dimasukkan dalam model penelitian ini.

Hasil Koefisien Determinasi (R2) (Persamaan 2) nilai R Square sebesar 0,634 atau $63,4 \%$. Hal ini menunjukkan bahwa persentase sumbangan pengaruh variabel independen, yaitu mental berwirausaha (X1), modal berwirausaha (X2) dan minat berwirausaha (Y1) terhadap variabel dependen yaitu motivasi berwirausaha (Y2) sebesar $63,4 \%$ sedangkan sisanya $36,6 \%$ dipengaruhi oleh variabel lain yang tidak dimasukkan dalam model penelitian ini.

\section{Pengaruh Mental Berwirausaha Terhadap Minat Berwirausaha}

Hasil penelitian sesuai dengan teori yang dikemukakan oleh Bygrave (2011:88) mengatakan salah satunya adalah faktor personal yaitu mental. Mental yang dimaksud adalah kesiapan diri dalam menghadapi segala tantangan dan resiko yang akan terjadi saat seseorang memutuskan untuk mulai berwirausaha. Apabila seseorang sudah memiliki mental yang kuat untuk berwirausaha maka ia pasti memiliki minat yang kuat dalam berwirausaha. Jadi bisa dikatakan bahwa mental berpengaruh terhadap minat berwirausaha.

Hasil penelitian ini juga didukung penelitian yang sebelumnya telah dilakukan oleh Ariyant (2018:78) yang berjudul "Pengaruh Motivasi Dan Mental Berwirausaha Terhadap Minat Berwirausaha Mahasiswa". Hasil penelitian menunjukkan bahwa motivasi berwirausaha berpengaruh positif dan 
signifikan terhadap minat berwirausaha dengan nilai signifikansi sebesar $0,012<0,05$

\section{Pengaruh Modal Berwirausaha Terhadap Minat Berwirausaha}

Teori yang dikemukakan Bygrave (2011:64) mengatakan bahwasanya faktor yang mempengaruhi minat berwirausaha lainnya adalah adanya sumber-sumber yang bisa dimanfaatkan seperti modal, tabungan, warisan, bangunan, dan lokasi strategis. Modal usaha merupakan salah satu faktor yang mempengaruhi minat seseorang berwirausaha . Modal ini dapat berupa uang ataupunbarang apa saja yang bisa digunakan untuk membuka suatu usaha. Dengan adanya modal usaha maka ia bisa membeli apapun yang ia butuhkan untuk membuka usaha. Karena adanya modal yang membuat seseorang bisa membeli apapun yang ia butuhkan untuk membuka usaha maka orang yang memiliki modal usaha cenderung akan lebih berminat berwirausaha daripada orang yang tidak memiliki modal usaha.

Hasil penelitian ini didukung dengan hasil penelitian sebelumnya oleh Penelitian yang dilakukan oleh Lubis (2017: 79-80) yang berjudul "Pengaruh Pemahaman Modal Usaha Dan Mental Wirausaha Terhadap Minat Berwirausaha Siswa Kelas X Smk Negeri 10 Muaro Jambi" . Hasil penelitian menunjukkan bahwa dari uji hipotesis pertama (X1) terhadap (Y) sebesar 0.636. Pada tabel tersebut nilai $\mathrm{t}$ sebesar 28.173 dengan sig $=0,00$ dengan kata lain pemahaman modal usaha berpengaruh terhadap minat berwirausaha, pada hipotesis kedua (X2 ) terhadap (Y) sebesar 0.590 atau dapat dinyatakan sebagai persamaan linier $\mathrm{Y}=$ 0.590 (X2).

\section{Pengaruh Mental Berwirausaha Terhadap Motivasi Berwirausaha}

Hasil penelitian didukung teori yang dikemukakan oleh Uno (2004:94) yang mengatakan mental juga ternyata berpengaruh terhadap motivasi seseorang dalam berwirausaha. Menurut Uno (2004:7) motivasi dibedakan menjadi dua macam, yaitu: motivasi intrinsik dan motivasi ekstrinsik. Salah satu motivasi intrinsik dalam motivasi berwirausaha adalah mental berwirausaha.

Hasil penelitian ini juga didukung penelitian yang sebelumnya telah dilakukan oleh Ariyant (2018:98) yang berjudul "Pengaruh Motivasi Dan Mental Berwirausaha Terhadap Minat Berwirausaha Mahasiswa". Hasil penelitian menunjukkan bahwa motivasi berwirausaha berpengaruh positif dan signifikan terhadap minat berwirausaha dengan nilai signifikansi sebesar $0,012<0,05$.

\section{Pengaruh Modal Berwirausaha Terhadap Motivasi Berwirausaha}

Hasil penelitian didukung teori yang dikemukakan Setiyawan (2015:76) mengatakan bahwasanya faktor yang mempengaruhi motivasi berwirausaha lainnya adalah adanya sumber-sumber yang bisa dimanfaatkan seperti modal, mental, minat dan prediksi masa depan. Modal usaha merupakan salah satu faktor yang mempengaruhi motivasi seseorang berwirausaha. Modal ini dapat berupa uang ataupun barang apa saja yang bisa digunakan untuk membuka suatu usaha. Karena adanya modal yang membuat seseorang bisa membeli apapun yang ia butuhkan untuk membuka usaha maka orang yang memiliki modal usaha cenderung akan lebih termotivasi berwirausaha daripada orang yang tidak memiliki modal usaha.

Hasil penelitian ini didukung oleh Penelitian yang dilakukan oleh Ariyant (2018:71) yang berjudul "Pengaruh Motivasi Dan Mental Berwirausaha Terhadap Minat Berwirausaha Mahasiswa". Hasil penelitian menunjukkan bahwa motivasi berwirausaha berpengaruh positif dan signifikan terhadap minat berwirausaha dengan nilai signifikansi sebesar $0,012<0,05$.

\section{Pengaruh Minat Berwirausaha Terhadap Motivasi Berwirausaha}

Hal tersebut didukung teori yang dikemukakan Fadli (2019: 121-122) mengatakan bahwasanya faktor yang mempengaruhi motivasi berwirausaha lainnya adalah adanya sumber-sumber yang bisa dimanfaatkan seperti modal, mental, minat dan prediksi masa depan. Minat dapat diartikan sebagai rasa senang atau ketertarikan terhadap sesuatu. Minat berwirausaha merupakan suatu ketertarikan, keinginan dan ketersediaan seseorang melalui ide dan inovasi yang dimiliki untuk bekerja keras untuk memenuhi kebutuhan hidupnya tanpa rasa takut dengan risiko yang akan terjadi, dapat menerima 
tantangan, percaya diri, kreatif dan inovatif, serta memiliki kemampuan dalam memenuhi kebutuhannya. Karena adanya minat berwirausaha yang tinggi pada mahasiswa maka hal ini secara langsung dapat mempengaruhi motivasi mahasiswa untuk berwirausaha lebih tinggi lagi.

Hasil penelitian ini juga didukung oleh Penelitian yang dilakukan oleh Anggraini (2015:103) yang berjudul "Pengaruh Motivasi,Mental Dan Modal Usaha Terhadap Minat Mahasiswa Akuntansi Untuk Berwirausaha (Studi Kasus Pada Mahasiswa Akuntansi Universitas Muhammadiyah Jember )". Hasil dari penelitian ini adalah (1) Motivasi memiliki nilai $\mathrm{t}$ hitung $-0,093<\mathrm{t}$ tabel 1,664 dan tingkat signifikan sebesar 0,926>0,05. Maka dengan kata lain hipotesis nol (H0) diterima

\section{Pengaruh Pengaruh Mental dan Modal terhadap Minat berwirausaha dengan Motivasi wirausaha sebagai Variabel Intervening}

Berdasarkan hasil penelitian yang dilakukan terdapat pengaruh yang positif dan signifikan antara mental berwirausaha dan modal berwirausaha terhadap minat berwirausaha dengan motivasi sebagai variabel intervening. Penelitian ini sejalan dengan penelitian yang dilakukan oleh Anggraini (2015:103) yang berjudul "Pengaruh Motivasi, Mental Dan Modal Usaha Terhadap Minat Mahasiswa Akuntansi Untuk Berwirausaha (Studi Kasus Pada Mahasiswa Akuntansi Universitas Muhammadiyah Jember )". Hasil dari penelitian ini adalah (1) Motivasi memiliki nilai t hitung $-0,093<\mathrm{t}$ tabel 1,664 dan tingkat signifikan sebesar 0,926>0,05. Maka dengan kata lain hipotesis nol (H0) diterima. Hal ini berarti motivasi berpengaruh negatif terhadap minat berwirausaha. (2) Mental memiliki nilai $\mathrm{t}$ hitung $0,947<\mathrm{t}$ tabel 1,664 dan tingkat signifikan sebesar 0,347>0,05 Maka dengan kata lain hipotesis nol (H0) diterima.

\section{KESIMPULAN DAN SARAN Kesimpulan}

Berdasarkan hasil penelitian dan pembahasan maka disimpulkan sebagai berikut: Secara parsial dan simultan menunjukkan bahwa variabel mental berwirausaha dan modal kewirausahaan berpengaruh secara positif dan signifikan terhadap minat berwirausaha.

\section{Saran}

Untuk meningkatkan minat berwirausaha mahasiswa maka diperlukan mental dan motivasi yang kuat dalam dirinya dengan cara menumbuhkan mental berwirausaha dalam dirinya sedini mungkin dengan mengikuti workshop, seminar dan pelatihan. Selain mental dan motivasi, modal usaha merupakan faktor yang sangat penting untuk membangun minat berwirausaha mahasiswa, peneliti menyarankan untuk menabung sejak dini sebagai modal untuk memulai usahanya.

\section{REFERENSI}

Alma. 2017. Kewirausahaan Untuk Mahasiswa dan Umum. Bandung: Alfabeta

Anggraini, Puput. Pengaruh Motivasi, Mental Dan Modal Usaha Terhadap Mahasiswa Akuntansi Untuk Berwirausaha (Studi Kasus Pada Mahasiswa Akuntansi Universitas Muhammadiyah Jember. Skripsi. Jember:Universitas Muhammadiyah Jember.

Arikunto, Suharsimi. 2015. Prosedur Penelitian Suatu Pendekatan Praktik. Jakarta: Rineka Cipta

Ariyanti, Anik . 2018 . Pengaruh Sikap Dan Motivasi Terhadap Minat Berwirausaha Siswa. Jurnal Pengembangan Wiraswasta. Vol 20, No.02

Basrowi. 2017. Kewirausahaan Untuk Peguruan Tinggi. Bandung: Alfabeta.

Busmin, Gurning. 2018. Metodologi penelitian pendidikan. Yogyakarta : K Media

Bygrave. 2011. Minat Berwirausaha dan Faktor Pendukung. Bandung: Alfabeta

Fadli. 2019. Motivasi dan Wirausahawan Sukses. Yogyakarta : K Media

Ghozali, Imam. 2016. Aplikasi analisis multivariate dengan program ibm spss

23. Semarang : Badan Penerbit Universitas Diponegoro

Gunarsa. 2015. Belajar dan Membelajarkan. Jakarta: Rajawali Press

Hantoro. 2015. Kiat Sukses Berwirausaha. Yogyakarta: Adicita Karya Nusa

Hendro. 2016. Dasar-Dasar Kewirausahaan. Jakarta: Penerbit Erlangga. 
Juanim.2015. Analisis Jalur dalam Riset Pemasaran. Bandung : Fakultas Ekonomi Universitas Pasundan.

Kasmir. 2016. Kewirausahaan. Jakarta : PT Raja Grafindo

Kuncoro. 2017. Cara Menggunakan dan Memaknai Analisis Jalur. Bandung : Alfabeta.

Kusnendi. 2016. Analisis Jalur: Konsep dan Aplikasi dengan Program SPSS \& Lisrel 8. Bandung: UPI Pendidikan Ekonomi,

Lubis. 2017. Pengaruh Pemahaman Modal Usaha Dan Mental Wirausaha Terhadap Minat Berwirausaha Siswa Kelas X SMK Negeri 10 Muaro Jambi.Skripsi. Jambi : FKIP Universitas Jambi.

Mardiyatmo. 2018. Kewirausahaan. Surakarta: Yudistira

Munawar. 2018. Pengaruh Sikap Dan Motivasi Terhadap Minat Berwirausaha Siswa. Jurnal Kajian Pendidikan Ekonomi dan Ilmu Ekonomi. Vol II No.1

Munawir. 2016. Analisis Laporan Keuangan. Yogyakarta : Liberty Yogyakarta,

Nitisusastro. 2016. Kewirausahaan dan Manajemen Usaha Kecil. Bandung: CV. Alfabeta

Paramitasari. 2016. Pengaruh Motivasi Berwirausaha dan Pengetahuan Kewirausahaan terhadap Minat Berwirausaha Siswa Kelas XI Kompetensi Keahlian Administrasi Perkantoran SMK N 1 Bantul. Skripsi. Yogyakarta: UNY.

Saiman, L. 2019. Kewirausahaan, Teori, Praktik, dan Kasus-kasus. Jakarta: Salemba Empat.

Setiawan. 2015. Minat Berwirausaha: Sebuah Teori dan Aplikasi. Jakarta : Salemba Empat

Sifa, Nurkhin. 2016. Pengaruh Pendidikan Kewirausahaan, Lingkungan Keluarga, dan Self Efficacy Terhadap Minat Berwirausaha Siswa kelas XI Program Keahlian Akutansi SMK Negeri 9 Semarang. Universitas Negeri Semarang, Indonesia. Economic Education Analysis Journal. p-ISSN 2252-6544, e-ISSN 2502-356X. Diakses 19 Oktober 2016

Siregar, Syofian. 2016. Statistika Deskriptif Untuk Penelitian. Jakarta: Rajawali Pers
Slameto. 2016. Belajar dan Faktor-Faktor yang Mempengaruhinya. Jakarta: Rineka Cipta.

Sofyan, H. \& Uno, B.H. 2016. Teori Motivasi dan Aplikasinya dalam Penelitian.Jakarta: Nurul Jannah.

Sugiyono. 2016. Statistika Untuk Penelitian. Bandung: Alfabeta

Sujanto. 2017. Psikologi Umum. Jakarta: Aksara.

Suryana. 2016. Kewirausahaan Pendekatan Karakteristik Wirausahawan Sukses. Jakarta: Kencana.

Suryabrata. 2018. Metodologi Penelitian. Jakarta: Rajawali Press.

Suryana. 2016. Kewirausahaan. Jakarta: Salemba Empat

Tjiptono F.2015. Manajemen Jasa Edisi Kedua. Yogyakarta : Andioffset

Uno. 2004. Cara Meningkatkan Minat dan Motivasi Berwirausaha. Yogyakarta : Andioffset

Wanto. 2017. Hubungan Kemandirian dan Motivasi Berwirausaha dengan Minat Berwirausaha Siswa Kelas SMK N 1 Seyegan. Skripsi. Yogyakarta: UNY

Winkel. 2016. Psikologi Pendidikan dan Evaluasi Belajar. Jakarta : Gramedia. 